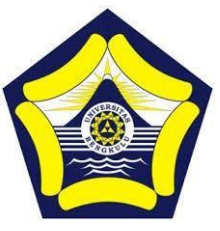

JOLL 4 (2) (2021)

Journal of Lifelong Learning

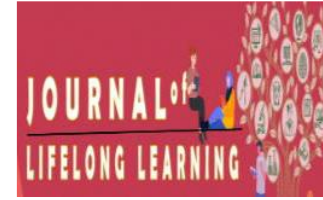

\title{
Harapan Stakeholder Tentang Kompetensi Lulusan Program Studi Pendidikan Nonformal Universitas Bengkulu
}

\author{
Endah Kristanti ${ }^{1}$, Rufran Zulkarnain ${ }^{2}$, Sofino ${ }^{3}$ \\ Pendidikan Nonformal, Universitas Bengkulu \\ endahkristantig6@gmail.com,rufranzulkaranain@unib.ac.id,Sofino@unib.ac.id
}

Abstrak

Tujuan dari penelitian ini untuk mengetahui harapan stakeholder tentang kompetensi lulusan Program Studi Pendidikan Nonformal Fakultas Keguruan Dan Ilmu Pendidikan Universitas Bengkulu. Penelitian ini merupakan penelitian kualitatif. Hasil penelitian menunjukkan, (1) Harapan stakeholder pada kompetensi aspek sikap adalah taat agama, cepat tanggap membantu teman sejawatnya, antusias pada saat hari besar nasional, , tanggap dalam memahami lingkungan sosialnya, disiplin, bertanggungjawab, memiliki keberanian. (2) Harapam stakeholder pada kompetensi aspek pengetahuan adalah mencari informasi perkembangan pendidikan nonformal, dapat mengetahui metode yang tepat bagi orang dewasa, mampu menyusun rancangan kegiatan pembelajaran, dapat memberikan ide yang terbaru terhadap pendidikan. (3) Harapan stakeholder pada kompetensi keterampilan umum adalah menunjukkan kinerja yang baik, dapat memberikan ide sesuai permasalahan, dapat mengaplikasikan teknologi baru, dapat menjalin kerjasama yang baik dapat merancang tata kelola lembaga pendidikan. (4) Harapan stakeholder pada kompetensi aspek keterampilan khusus adalah, mengembangkan program di lembaga PNF, mampu mengembangkan rancangan pengelolaan lembaga PNF, dapat mengembangkan potensi masyarakat.

Kata Kunci: Harapan, Stakeholder, Kompetensi Lulusan Pendidikan Nonformal.

\begin{abstract}
The purpose of this study was to determine stakeholder expectations regarding the competence of graduates of the Non-formal Education Study Program, Faculty of Teacher Training and Education, Bengkulu University. This research is a qualitative research. The results of the study show, (1) Stakeholders' expectations on the competence aspect of attitude are religious obedient, responsive to helping their colleagues, enthusiastic on national holidays, responsive in understanding their social environment, disciplined, responsible, having courage. (2) The expectations of stakeholders on the competence aspect of knowledge are seeking information on the development of non-formal education, being able to find out the right method for adults, being able to design learning activities, being able to provide the latest ideas for education. (3) The expectations of stakeholders in general skills competence are showing good performance, being able to provide ideas according to problems, being able to apply new technology, being able to establish good cooperation and being able to design the governance of educational institutions. (4) The expectations of stakeholders on the competence aspect of special skills are, developing programs in PNF institutions, being able to develop management plans for PNF institutions, being able to develop community potential.
\end{abstract}

Keywords: Expectations, Stakeholders, Competencies of Non-Formal Education Graduates. 


\section{PENDAHULUAN}

Menurut Pasal 2 Undang-Undang Nomor 20 Tahun 2003 tentang Sistem Pendidikan Nasional, bahwa pendidikan nasional berdasarkan Pancasila dan Undang-Undang Dasar Negara Republik Indonesia Tahun 1945. Dan dalam Pasal 3 juga menegaskan bahwa Pendidikan nasional berfungsi mengembangkan kemampuan dan membentuk watak serta peradaban bangsa yang bermartabat dalam rangka mencerdaskan kehidupan bangsa, bertujuan untuk mengembangkan potensi peserta didik agar menjadi manusia yang beriman dan bertakwa kepada Tuhan Yang Maha Esa, berakhlak mulia, sehat, berilmu, cakap, kreatif, mandiri, dan menjadi warga negara yang demokratis serta bertanggung jawab.

Untuk mewujudkan tujuan pendidikan nasional tersebut diperlukan profil kualifikasi kemampuan lulusan yang dituangkan dalam standar kompetensi lulusan. Dalam penjelasan Pasal 35 Undang-Undang Nomor 20 Tahun 2003 disebutkan bahwa standar kompetensi lulusan merupakan kualifikasi kemampuan lulusan yang mencakup sikap, pengetahuan, dan keterampilan peserta didik yang harus dipenuhinya atau dicapainya dari satuan pendidikan pada jenjang Perguruan Tinggi.

Kompetensi merupakan suatu kemampuan untuk melaksanakan atau melakukan suatu pekerjaan atau tugas yang dilandasi atas keterampilan dan pengetahuan serta didukung oleh sikap kerja yang dituntut oleh pekerjaan tersebut, namun yang menjadi salah satu permasalahan adalah kompetensi yang dimiliki seorang sarjana tidak sesuai dengan kebutuhan. Hal ini merupakan permasalahan kualitas lulusan dan kompetensi yang terjadi dilapangan.
Kesiapan seorang sarjana lulusan perguruan tinggi yang lebih memiliki bekal ilmu dan luas pengetahuannya, lebih mantap profesionalitas dan pengalamannya serta memiliki semangat wirausaha dengan jiwa kepemimpinan yang matang sebagai sumber daya manusia penggerak ekonomi seharusnya bebas dari masalah pengangguran, nyatanya realita di lapangan tidak begitu karena kompetensi yang dimiliki tidak sesuai kebutuhan. Sehingga pengangguran terdidik bagi para lulusan universitas telah memperbesar angka pengangguran.

Menurut Badan Pusat Statistik (BPS) periode Februari 2019 jumlah pengangguran lulusan diploma dan universitas naik yaitu sebesar $8,5 \%$ pada tingkat diploma dan $25 \%$ pada tingkat universitas yang mana salah satu penyebabnya dikarenakan keterampilan tidak sesuai kebutuhan. Tidak mengherankan jika lulusan sarjana masih kesulitan memperoleh pekerjaan yang sesuai dengan kemampuan dirinya saat ini. Tingkat pengangguran yang dialami oleh para alumni perguruan tinggi ini menandakan para sarjana masih menjadi momok yang harus segera diatasi sebagai upaya penekanan angka pengangguran di negeri ini.

Mensikapi berbagai kondisi tersebut di atas, Universitas Bengkulu sebagai salah satu institusi pendidikan tinggi diharapkan dapat menghasilkan lulusan yang dapat diserap dunia kerja.

Dalam memenuhi tuntutan tersebut ada beberapa isu yang dihadapi yaitu kualitas pendidikan dan relevansi antara kompetensi dengan kebutuhan pasar. Maka dari itu, peningkatan kualitas lulusan adalah jawaban terhadap isu tersebut, karena dengan upaya tersebut Universitas Bengkulu dapat mempersiapkan isi dan sistem pendidikannya agar lulusan yang 
dihasilkan dapat berkompetisi di dunia kerja, serta sesuai dengan keinginan stakeholder. Oleh karena itu, isu tersebut, hendaknya dapat dijadikan dasar dalam rangka peningkatan kualitas mutu pendidikan yang diselenggarakan oleh Universitas Bengkulu dengan melakukan langkah strategis guna menjaga eksistensi dan kualitasnya sebagai universitas yang unggul, terkemuka dan terpercaya dalam pandangan stakeholder.

Program Studi S1 Pendidikan Nonformal sebagai bagian dari Fakultas Keguruan dan Ilmu Pendidikan Universitas Bengkulu yang mana program S1 Pendidikan Nonformal didirikan berdasarkan surat keputusan Dirjen Dikti Nomor : 775/D/T/2002 tanggal 23 april 2002, ditetapkan nama program studi Pendidikan Luar Sekolah dan telah menghasilkan sarjana-sarjana Pendidikan Luar sekolah.

Sesuai dengan perkembangan ilmu dan kebutuhan Stakeholder pada tahun 2014 Direktur Pembelajaran dan Kemahasiswaan Derektorat Jendral Pendidikan Tinggi Kementrian Pendidikan dan Kebudayaan RI melalui suratnya Nomor : 2300/E3/2014 Tanggal 28 Mei 2014 perihal tentang perubahan nomenkelatur program studi, meminta Rektor Universitas Bengkulu mengirimkan Perubahan Nomenklatur Program Studi, pada surat Rektorat Universitas Bengkulu Nomor : 6290/UN30/EP/2014, tanggal 26 Juni 2014 tentang perubahan Nomenklatur Program Studi. Semenjak tanggal tersebut Program Studi Pendidikan Luar Sekolah berganti nama dengan Program Studi Pendidikan Nonformal.

Sejak tahun 2002, Prodi S1 Pendidikan Nonformal telah melakukan evaluasi kurikulum berdasarkan masukan dan dan pertimbangan kebaruan keilmuan pendidikan nonformal. Pembaharuan itu juga dilandasi oleh dinamika dan tuntutan pasar yang memerlukan tenaga kerja yang terampil dan profesional. Sebagai Program Studi Pendidikan Nonformal satu-satunya yang ada di kota Bengkulu, maka prodi Pendidikan Nonformal telah memuat standar kompetensi lulusan yang terstruktur dalam kompetensi utama, pendukung dan lainnya yang sangat relevan dengan pranata dan nilai-nilai program studi pendidikan nonformal.

Menurut Kurikulum Program Studi Pendidikan Nonformal kompetensi lulusan Program Studi Pendidikan Nonformal yaitu :

1. Kompetensi utama

a. Kompetensi aspek sikap.

b. Kompetensi aspek pengetahuan.

c. Kompetensi aspek keterampilan umum.

d. Kompetensi aspek keterampilan khusus

2. Kompetensi pendukung lulusan

a. Kemampuan bekerjasama dalam tim yang multidisiplin.

b. Mampu bertanggung jawab, profesional dan memiliki etika yang baik.

c. Kemampuan berkomunikasi secara efektif.

d. Mampu mencermati peluang baik dimasyarakat maupun di pemerintahan.

3. Kompetensi lainnya/pilihan lulusan

a. Kemampuan memahami tahapan bisnis untuk mengembangkan teknologi, pemberdayaan ekonomi dan konsep bisnis menuju komersialisasi.

Lulusan S1 pendidikan nonformal diarahkan pada calon pendidik dan kependidikan pendidikan nonformal yang unggul sesuai dengan visi dan misi dari program studi pendidikan nonformal. 
Kompetensi lulusan prodi pendidikan nonformal yang telah dimuat secara struktur tidak akan mencapai kompetensi yang diharapkan jika tidak didukung oleh sistem pembelajaran yang memadai dan sesuai dengan tuntutan dunia kerja. Apalagi, semakin besar lulusan yang diserap dunia kerja, maka program studi tersebut semakin diminati oleh calon mahasiswa. Begitu juga sebaliknya, jika program studi tidak mampu melahirkan sarjana-sarjana yang siap diserap dunia kerja, maka akan ditinggalkan oleh calon mahasiswa.

Kajian tentang lulusan perguruan tinggi bukanlah merupakan kajian yang baru, Sebelumnya telah ada beberapa penelitian yang kebanyakan berkaitan dengan tracing study lulusan, kompetensi lulusan dan penguatan kurikulum. Namun, penelitian yang terkait dengan stakeholder pengguna lulusan sangatlah sedikit.

Kajian mengenai tracer study alumni pendidikan nonformal FKIP UNIB menyatakan kesesuaian kompetensi dengan bidang kerja lulusan program studi tahun 2013-2017 adalah 70\% yang berarti cukup sesuai dengan lama masa tunggu pekerjaan yaitu o bulan sampai 12 bulan dari semenjak lulus dari program studi Pendidikan Nonformal.

Berdasarkan informasi dari hasil wawancara kepada salah satu kepala lembaga pengguna lulusan program studi pendidikan nonformal pada 20 Februari 2020 yaitu kepada bapak Apen Putra Utama selaku ketua yayasan Pusat Kegiatan Belajar Masyarakat Bahari dan Pariwisata Kota Bengkulu menyatakan harapannya dimana kompetensi yang dibutuhkan lembaga yang harus dimiliki lulusan yaitu kejujuran, keterampilan dalam menyalurkan ilmu pendidikan nonformal, dan pengetahuan teknologi komputer.

Dari infomasi data yang didapat dimana menurut KEPMENDIKNAS Nomor 045 Tahun 2002 bahwa kurikulum inti merupakan penciri dari kompetensi utama yang mana kompetensi utama memiliki ciri khas yaitu sebagai pembeda antara program studi satu dengan lainnya yang memiliki perbandingan ekivalen dalam Perbandingan beban ekivalen dalam bentuk satuan kredit semester antara kompetensi utama dengan kompetensi pendukung serta kompetensi lain di dalam kurikulum berkisar antara $40-80 \%: \quad 20-40 \%: \quad 0-30 \%$. Ini menunjukkan bahwa kompetensi utama memiliki ekivalen terbesar diantara kompetensi pendukung dan lainnya.

Berdasarkan uraian latar belakang di atas maka peneliti tertarik untuk mengadakan penelitian yang lebih spesifik dan lebih terfokus terhadap kompetensi utama yaitu dengan judul "Harapan Stakeholder Tentang Kompetensi Lulusan Program Studi Pendidikan Nonformal Universitas Bengkulu"

\section{METODE}

Penelitian ini dilaksanakan dengan menggunakan metode deskriptif kualitatif yang mendeskripsikan fenomena yang ada akan diperoleh pemahaman dari penafsiran serta realitas dan mendalam mengenai makna dari kenyataan dan fakta yang ada, karena permasalahan dalam penelitian ini tidak dengan angka-angka akan tetapi mendeskripsikan, menguraikan dan menggambarkan tentang "Harapan Stakeholder tentang Kompetensi Lulusan Program Studi Pendidikan Nonformal Fakultas Keguruan dan Ilmu Pendidikan Universitas Bengkulu " yang mencakup aspek-aspek kompetensi yang dimiliki lulusan yaitu 
aspek sikap, aspek pengetahuan, aspek keterampilan umum dan aspek keterampilan khusus.

Penelitian dilaksanakan di tiga lembaga yaitu SKB Argamakmur, PKBM Songgo Langit Kota Bengkulu dan PKBM Bahari dan Pariwisata Kota Bengkulu. Alasan memilih ketiga lembaga tersebut karena relevan dengan kompetensi yang dimiliki lulusan dan di ketiga lembaga PNF tersebut terdapat lulusan Prodi PNF FKIP UNIB tahun 2018.

Teknik pengumpulan data merupakan langkah yang paling strategis dalam penelitian, karena tujuan utama dari penelitian adalah mendapatkan data. Adapun teknik yang digunakan dalam penelitian ini adalah adalah observasi berkaitan dengan perilaku manusia, proses kerja, gejala-gejala alam dan apabila responden diambil tidak terlalu besar. mengumpulkan dokumen-dokumen pendukung untuk melengkapi data penelitian.

Untuk menguji validitas data, peneliti menggunakan teknik triangulasi. Sebagaimana pendapat Meleong (2005:330) “Teknik triangulasi adalah teknik pemeriksaan validitas data yang memanfaatkan suatu yang lain. Diluar data itu untuk keperluan pengecekan atau sebagai perbandingan terhadap data itu".

Selain itu peneliti melakukan analisis data meliputi reduksi data (data reduction) merupakan pengumpulan data penelitian. Setelah data di reduksi, maka langkah selanjutnya adalah penyajian data (data display) dan penarikan kesimpulan (verification).

\section{HASIL DAN PEMBAHASAN}

\section{Menurut Peraturan Menteri}

Pendidikan Dan Kebudayaan Republik Indonesia Nomor 3 Tahun 2020 Tentang Standar Nasional Pendidikan Tinggi
(2020:7), sikap merupakan perilaku benar dan berbudaya sebagai hasil dari internalisasi dan aktualisasi nilai dan norma yang tercermin dalam kehidupan spiritual dan sosial melalui proses Pembelajaran, pengalaman kerja mahasiswa, Penelitian dan/atau Pengabdian kepada Masyarakat yang terkait Pembelajaran.

Hasil observasi, wawancara dan dokumentasi yang dilakukan bahwa pada kompetensi aspek sikap yang dimiliki lulusan, stakeholder memiliki harapan lulusan dapat taat menjalankan ibadah, cepat tanggap membantu teman sejawatnya yang mendapatkan musibah bahkan juga dapat membantu diluar lingkungan lembaga tempatnya bekerja, bangga sebagai bagian dari penduduk indonesia dan antusias untuk ikut upacara pada saat memperingati hari-hari besar nasional, mampu menjadi pelopor untuk memajukan masyarakat, dapat tanggap untuk memahami lingkungan sosialnya terhadap setiap permasalahan yang ada, menghargai perbedaan yang ada di lingkungan kerja, dapat disiplin, taat aturan dan dapat menunjukkan sikap bertanggungjawab terhadap tugas, memiliki keberanian menghadapi tantangan yang ada sehingga dapat membuka usaha sendiri atau dapat membuka usaha berbasis masyarakat.

Berdasarkan Peraturan Menteri Pendidikan Dan Kebudayaan Republik Indonesia Nomor 3 Tahun 2020 Tentang Standar Nasional Pendidikan Tinggi (2020:7), pengetahuan merupakan penguasaan konsep, teori, metode, dan/atau falsafah bidang ilmu tertentu secara sistematis yang diperoleh melalui penalaran dalam proses Pembelajaran, pengalaman kerja mahasiswa, Penelitian dan/atau Pengabdian kepada Masyarakat yang terkait Pembelajaran. 
Hasil observasi, wawancara dan dokumentasi yang dilakukan bahwa pada kompetensi aspek pengetahuan yang dimiliki lulusan, stakeholder memiliki harapan lulusan dapat terus mencari informasi dan pengetahuan yang terus mengalami perkembangan dalam pendidikan dapat mengetahui secara keseluruhan konsep dasar pendidikan sepanjang hayat dari landasan, pengertian, tujuan, peran dan ciri-ciri bahkan juga dapat mengetahui proses berlangsungnya pendidikan sepanjang hayat serta sasarannya, mengetahui dan mengaplikasikan metode dan media yang tepat untuk menumbuhkan semangat belajar bagi orang dewasa, mengetahui ruang lingkup program kesetaraan dan dapat menyusun rancangan kegiatan pembelajar dalam program pendidikan kesetaraan, menyusun perencanaan lembaga pendidikan sesuai dengan 8 standar nasional pendidikan dan dapat mengembangkan lembaga lebih baik lagi sehingga lembaga pendidikan akan menjadi berkualitas dan grade akreditasinya akan lebih baik, dapat memberikan ide dan perencanaan pengembangan model yang baru, menciptakan sesuatu yang terbaru sesuai dengan perkembangan teknologi yang pesat, dan dapat memberikan ide dan usulan terhadap penilaian pendidikan sesuai dengan kebutuhan masyarakat.

Berdasarkan Peraturan Menteri Pendidikan Dan Kebudayaan Republik Indonesia Nomor 3 Tahun 2020 Tentang Standar Nasional Pendidikan Tinggi (2020:7-8), keterampilan umum sebagai kemampuan kerja umum yang wajib dimiliki oleh setiap lulusan dalam rangka menjamin kesetaraan kemampuan lulusan sesuai tingkat program dan jenis Pendidikan Tinggi.
Hasil observasi, wawancara dan dokumentasi yang dilakukan bahwa pada kompetensi aspek pengetahuan yang dimiliki lulusan, stakeholder memiliki harapan lulusan dapat menunjukkan kinerja yang baik dalam setiap pekerjaannya dan dapat mengukur apa yang harus di kerjakan sesuai standar yang telah ditetapkan, dapat memberikan ide yang mudah dimengerti dan sesuai dengan permasalahan permasalahan yang ada serta memberikan inovasi yang berkelanjutan, dapat mengaplikasikan teknologi-teknologi baru yang sedang berkembang dan dapat lebih meningkatkan kemampuannya menguasai teknologi-teknologi yang lain, skripsi yang telah dibuat atau dihasilkan oleh lulusan PNF dapat dipublikasikan, dapat membuat suatu ide atau perencanaan program pendidikan dan bisa melakukan penilaian terhadap perencanaan yang telah dilaksanakan sehingga program berkepanjangan sehingga lembaga pendidikan ini bisa di kenal di masyarakat, menjalin kerjasama dan komunikasi yang baik antara sejawat dan koleganya baik itu di dalam lembaga tempatnya bekerja maupun di luar lembaga itu sendiri, dapat melakukan pekerjaannya dengan prima dan dapat mempertanggungjawabkan segala bentuk tugas yang telah diberikan dan dapat merancang tata kelola lembaga mulai dari perencanaan melaksanakan, mengevaluasi sesuai aturan 8 standar pendidikan.

Berdasarkan Peraturan Menteri Pendidikan Dan Kebudayaan Republik Indonesia Nomor 3 Tahun 2020 Tentang Standar Nasional Pendidikan Tinggi (2020:8), keterampilan khusus sebagai kemampuan kerja khusus yang wajib dimiliki oleh setiap lulusan sesuai dengan bidang keilmuan Program Studi. 
Hasil observasi, wawancara dan dokumentasi yang dilakukan bahwa pada kompetensi aspek pengetahuan yang dimiliki lulusan, stakeholder memiliki harapan lulusan dapat memiliki inisiatif untuk memberikan usul, ide atau gagasan pemikiran yang dapat dimengerti dan tidak hanya menerima pendapat-pendapat yang lainnya akan tetapi dapat membereikan pendapat juga, bisa lebih menguasai teknologi-teknologi dan bisa bisa meningkatkan kemampuannya dalam bidang IPTEK, dapat melakukan pengembangan terhadap programprogram yang ada di lembaga ini terutama lembaga PNF berdasarkan tata cara dan etika ilmiah dalam rangka menghasilkan solusi,gagasan atau usul, mampu mengembangkan lembaga PNF melalui rancangan pengelolaan lembaga PNF baik dari perencanaan, pelaksanaan dan pengembangan pendidikan nonformal dan mampu mengendalikannya, bisa berani menghadapi tantangan, hambatan dan dapat melaksanakan komunikasi yang baik dengan masyarakat sehingga dapat menciptakan sesuatu yang bernilai kewirausahaan yang dapat digunakan dalam mengembangkan potensi yang ada di masyarakat dan dapat menjalin, memupuk dan memelihara tali silaturahmi dan komunikasi yang baik diantara kolega dan sejawatnya baik di dalam lembaga PNF maupun di luar lembaga PNF.

\section{KESIMPULAN}

Berdasarkan tujuan penelitian, hasil penelitian dan pembahasan maka dapat disimpulkan bahwa harapan stakeholder tentang aspek sikap yang dimiliki lulusan yaitu, lulusan dapat taat menjalankan ibadah, cepat tanggap membantu teman sejawatnya yang mendapatkan musibah bahkan juga dapat membantu diluar lingkungan lembaga tempatnya bekerja, bangga sebagai bagian dari penduduk indonesia dan antusias untuk ikut upacara pada saat memperingati hari-hari besar nasional, mampu menjadi pelopor untuk memajukan masyarakat, dapat tanggap untuk memahami lingkungan sosialnya terhadap setiap permasalahan yang ada, menghargai perbedaan yang ada di lingkungan kerja, dapat disiplin, taat aturan dan dapat menunjukkan sikap bertanggungjawab terhadap tugas, memiliki keberanian menghadapi tantangan yang ada sehingga dapat membuka usaha sendiri atau dapat membuka usaha berbasis masyarakat.

\section{DAFTAR PUSTAKA}

Arikunto, Suharsimi. 2006. Dasar-Dasar Evaluasi Pendidikan. Jakarta: Bumi Aksara.

Arikunto, Suharsimi.2010. Prosedur Penelitian. Jakarta: PT Rineka Cipta.
Borang Akreditasi Program Studi Pendidikan Nonformal 2018 http://pendidikanluarsekolahunp.bl ogspot.com/2011/o6/konsep- pendidikan-luar-sekolah.html

Moeleong. 2014. Metodelogi Penelitian Kualitatif Bandung : Rosdakarya.

Moeleong, Lexy. (2002). Metodelogi Penelitian Kualitatif. Bandung: PT remaja Rosdakarya

PP Nomor 17 Tahun 2010 Tentang Pengelolaan dan Penyelenggaraan Pendidikan

Sudjana, Djuju. 2001. Pendidikan Nonformal: Wawasan, Sejarah Perkembangan, Falsafah \& Teori 
Pendukung, serta Asas.

Bandung:Falah Production.

Sutarto, Joko. 2007. Pendididkan

Nonformal (Konsep Dasar, Proses

Pembelajaran \& Masyarakat).

Semarang: UNNES PRESS

Suprihatiningrum, Sugiyono. (2013).

Metodologi Penelitian Pendidikan:

Pendekatan Kuantitatif,

Kualitatif, Dan RED. Bandung:

Alfabeta. 